\title{
Sources for Tudor and Stuart History: The William Clarke Papers
}

by

\section{A. J. Hobbins}

This paper describes the Tudor and Stuart British history collection at McGill University. After some general consideration of the historic and contemporary strengths, it focuses on the microform collection of the papers of Sir William Clarke. In describing Clarke's life and career, of which not a tremendous amount is known for certain, some assumptions made by a variety of historians are challenged. The description of the papers themselves includes a discussion of the scholarly use already made of them and notes which parts have been transcribed and published. Clarke's shorthand is considered with especial reference to the solution or key.

Cet article décrit la collection d'histoire de Grande-Bretagne sous les Tudor et les Stuart que possède l'université McGill. Après quelques généralités sur la valeur historique et contemporaine des meilleurs éléments de cette collection, l'auteur s'intéresse à la collection sur micro-fiches des écrits de Sir William Clarke. Dans sa description de la vie et de la carrière de Clarke, dont on ne connaît pas grand chose, l'auteur conteste certaines des hypothèses émises par divers historiens. La description des écrits proprement dits comporte un exposé de l'usage érudit qui en a été fait et mentionne les parties qui on déjà été transcrites et publiées. La sténo de Clarke est analysée par rapport à la solution ou clé.

Sources for the Tudor and Stuart periods of British history have always been an area of especial strength in the McGill University Libraries. Impetus for this interest was most of ten spurred by ownership of a collection of some 20,000 political and religious pamphlets known as the Redpath Tracts, which were donated by Peter Redpath ${ }^{1}$ in 1884 and also by his widow in 1901. The core of the collection was gathered by Sir John Bramston ${ }^{2}$ during the Civil War and Restoration periods, but much has been added since. The collection now covers 1561-1900, with its greatest emphasis on the Stuart period.

For over a century the Redpath Tracts were recognized by scholars and in library surveys ${ }^{3}$ as a uniquely valuable resource for the study of British history. However, with the passing of time, the value to researchers of this and similar collections tends to diminish as ever greater proportions of the titles are made available in microform. Short title catalogue based collections, ${ }^{4}$ covering English language titles published 1475-1900, are at various stages of completion. Smaller projects of great utility, such as the Thomason Tracts $^{5}$ or the Goldsmith-Kress library, ${ }^{6}$ have also been made available. The Redpath Tracts remain, of course, of very great value for the unique titles not yet microfilmed and for occasions when the scholar must use an original edition.

The microform revolution has created a situation where most titles 
printed in Tudor and Stuart times are or will be soon readily available. Some microform publishers are moving beyond the printed word to manuscript sources. Of particular interest to Tudor and Stuart scholars is the work being done by Harvester Microform, who have published large quantities of papers and manuscripts in public and private hands. The drawback to these exciting projects from the library perspective is the great cost involved in acquiring the sets. Few libraries, especially in Canada in the 1980 's, could purchase anything other than a tiny fraction of what is available without outside financial help.

In 1984 McGill University Libraries made an application to the Social Science and Humanities Research Council of Canada "Support to Specialized Collections" Program. The application was based on the known existing strength of the general and special collections for the study of Tudor and Stuart History. It successfully sought financial aid in the purchase of Harvester Microform materials. ${ }^{7}$ With the help of these grants, McGill University has been able to acquire, catalogue and make available for scholarly use the following collections: ${ }^{8}$

Politics and Statecraft in Early Modern England: The Main Papers of the House of Lords, 1509-1715.

The Complete State Papers Domestic. Series I, 1547-1625. Series II, 1625-1702.

\section{Unpublished State Papers of the English Civil War and Interregnum.}

Social and Political Affairs in the Age of the Tudors: The Talbot Papers from the Lambeth Palace Library, London.

The Uncalendared State Papers Foreign of Elizabeth I, [May 1592 - March, 1603].

Not yet acquired but highly desirable are the manuscripts from the Harleian, Rawlinson, Ballard, Tanner, Hastings and Lansdowne Collections. ${ }^{9}$

Almost lost in these other long and important sets is one of only seventeen reels acquired in 1987. It is entitled by Harvester Parliament, The Civil War, The Conquest and Administration of Scotland, 1640-1664. It consists of the papers of Sir William Clarke, the vast majority of which are in Worcester College, Oxford. The greater part of these had been left to the College by Clarke's son, Dr. George Clarke, 1661-1736. Most of the rest, which had gone, probably in error, to an heir of his executor, were later acquired by Worcester College. The final reels deal with other Clarke papers in locations such as the National Library of Scotland, Library of Chequers Court, etc.

\section{Sir William Clarke's Career}

Clarke's early life is very obscure. Nothing is known of his parents, ${ }^{10}$ but he is thought to have been born in or near London in or around 1623 . 
He is alleged to have been admitted to the Inner Temple in 1646 and called to the bar in $1653 .{ }^{11}$ He was certainly a member of the Army Secretariat in 1646 and 1647, serving under John Rushworth, ${ }^{12}$ and may have been on the parliamentary clerical staff from as early as 1640 .

Clarke was a Secretary to the General Officers of the Parliamentary Army, with a specific responsibility for the Army council from 1647 to 1649. In this latter role he took down in shorthand the discussions which later became known as the Army Debates and threw so much light on the split between Army and Parliament. ${ }^{13} \mathrm{He}$ did not transcribe these notes into longhand until after the Restoration, problably in $1662 .{ }^{14} \mathrm{He}$ was also secretary to various commissioners, such as those who negotiated the surrender of Oxford in 1646 and those who attempted to arrange terms between Parliament and Army in $1647 .{ }^{15}$ There is a possibility he was present on the scaffold in 1649, taking down the King's last words, but this is by no means certain. ${ }^{16}$ At this time he was Lord General Fairfax's cosecretary, ${ }^{17}$ and had been present at the King's trial. ${ }^{18}$

With Fairfax's resignation in 1650 , the Scottish phase of Clark's career began. Cromwell, returning from Ireland, succeeded to the post of Lord General and led a preemptive strike against the Scots. Clarke went to Scotland with Cromwell, serving in various capacities. His applications to serve as the Secretary to the Committee of the Army in October, 1650, and Keeper of the Scottish Records in August, 1651, were unsuccessful. Clarke's official gains, however, were sufficient to allow him to purchase a large estate in St. John's Wood. ${ }^{19}$ Cromwell pursued Charles II into England after the fall of Perth in August 1651, while Clarke remained in Scotland as Secretary to Lieutant-General George Monck, the acting Commander-in-chief. Although Monck retired for health reasons later that year and was followed by several commanders in rapid succession, he did return in 1654 . For the next twelve years Clarke served Monck, who viewed him as a "faithful and indefatigable servant, ${ }^{20}$ and his fortunes rose as a result.

In January 1660, Monck marched his army into England. In the ensuing months and with the aid of Fairfax, he gained sole control of the army as Captain-General. It is uncertain when he began to favour the restoration of the monarchy, perhaps as early as July 1659. Regardless of when his conversion occurred, he, the most influential individual in the kingdom, was in favour of restoration when the question came before Parliament in May 1660. Under the restored monarchy he was elevated to the peerage and obtained the King's favour for a number of his friends and followers.

Clarke was knighted and made Secretary-at-War. In addition he was given a lodge and sixty acres of land in Marylebone Park. ${ }^{21}$ In October 1660, he appeared as a witness in the trials of the regicides Thomas Harrison, Adrian Scroop, John Carew, Thomas Scot, and John Jones. ${ }^{22} \mathrm{He}$ testified as to whether each one was present on the final day of Charles I's trial in the High Court of Justice on January 27, 1649. ${ }^{23}$ After this task, he busied himself with affairs of state. His son, George, was born in 1661 .

In the spring of 1666, Monck put to sea in the "Royal Charles" to sail against the Dutch. Clarke went with him and was wounded in battle on June 2, dying two days later. Lady Clarke was married again very shortly to 
Samuel Barrow, an old friend of her husband. Barrow provided a fine home and education for George Clarke, who became Secretary-at-War in his turn. When George retired from public life to Oxford, several colleges benefitted from his philanthropy. Thus his father's papers were deposited and preserved in a place where their importance would be discovered in a century and a half.

\section{The Clarke Papers}

The actual papers are, as one might suspect, an amorphous mixture of private and public documents from all periods of Clarke's career. Most are in longhand (Figure 6), many in shorthand (Figure 7), and some are in both. Harvester Microform have divided the papers into four series which do not correspond with the Worcester College Library arrangement. These are:

1. Letters and papers relating to the Army and Army matters in Scotland, 1640-1664.

2. Letters and other papers dealing with the Army, its relations with Parliament and military proceedings, including the Putney, Reading and Whitehall debates, 1640-1660.

3. Letter-books, abstracts of orders, warrants and passes and other materials dealing with the Army in Scotland and General Monck as Commander-in-Chief, 1652-1665.

4. Miscellaneous items, including unbound documents and volumes containing papers relating closely to, though not of, William Clarke.

The first historian to make extensive use of the papers was Sir Charles Firth towards the end of the 19 th century. Since then they have become an indispensable source for most studies of the period, especially regarding military history. Some portions of the papers have been published, the most extensive of which are the following:

Firth, C. H. The Clarke Papers. 4 vols. London, 1891-1901. (Camden Society. Publications. New Series. Vols. 49, 54, 61-62).

Firth, C. H. Scotland and the Commonwealth. Edinburgh, 1895. (Scottish History Society. Publications. Vol. 18).

Firth, C. H. Scotland and the Protectorate. Edinburgh, 1899. (Scottish History Society. Publications. Vol. 31).

Woodhouse, A. S. P. Puritanism and Liberty. 2nd ed. London, 1951.

This represents a different analysis of the Army Debates, 1647-9, first appearing in Firth's The Clarke Papers.

Great Britain Historical Manuscripts Commission. Report on the Manuscripts of F.W. Leyborne-Popham, Esq.. of Littlecote, Co. 


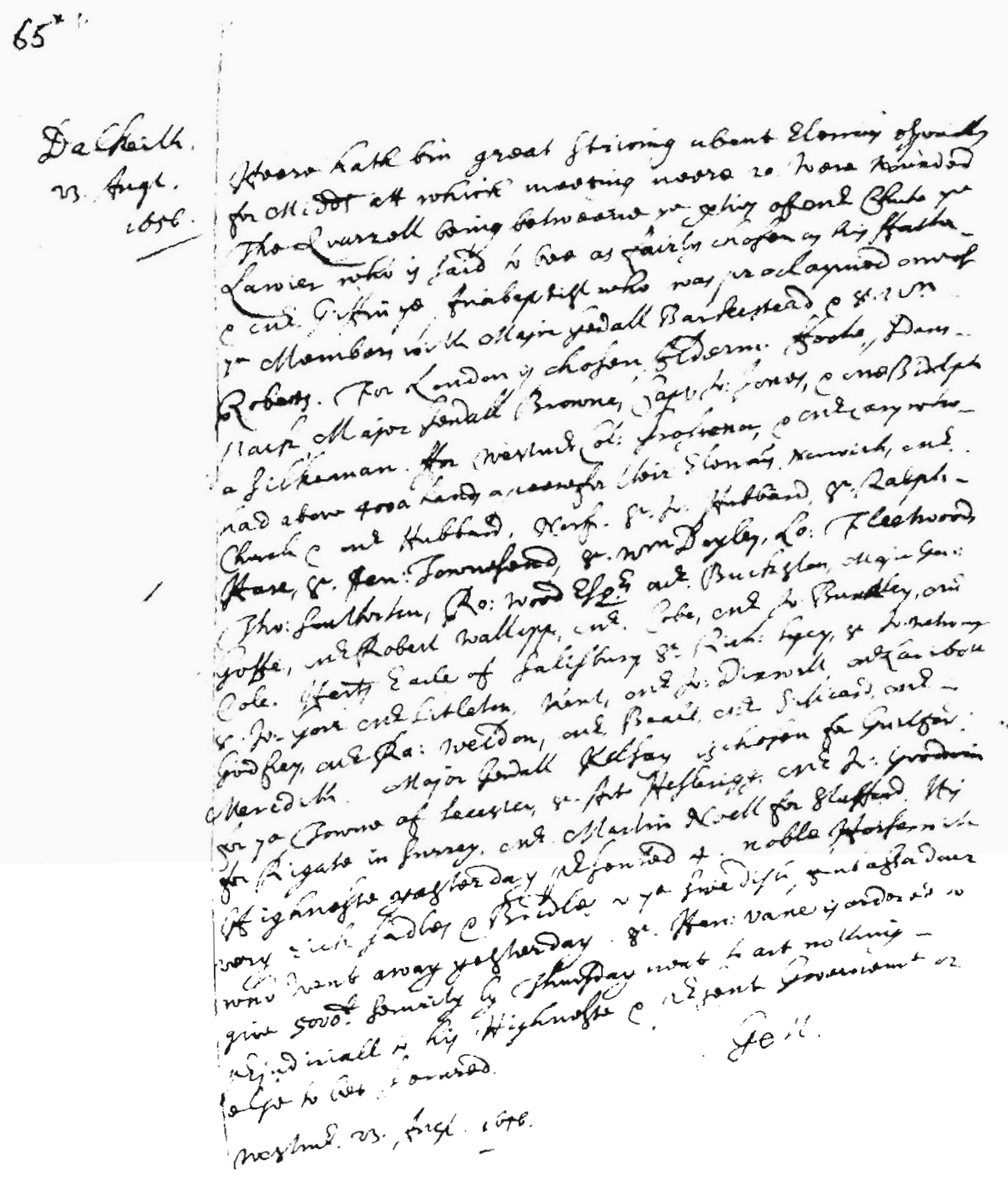

Fig. 6. A newsletter dated 23 August, 1656, from Gilbert Mabbott. (Courtesy of the Provost and Fellows of Worcester College, Oxford, and Harvester Microforms, see Note 36) 


$$
\begin{aligned}
& \text { Fackith. … }
\end{aligned}
$$

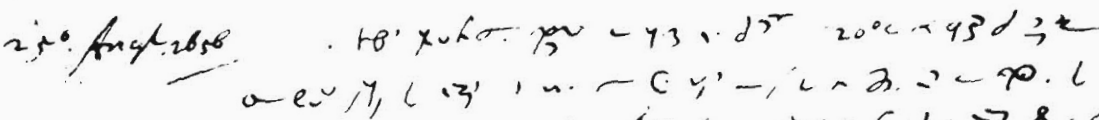

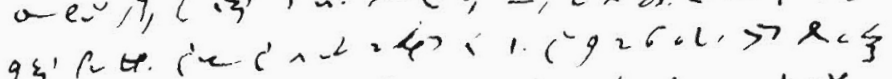

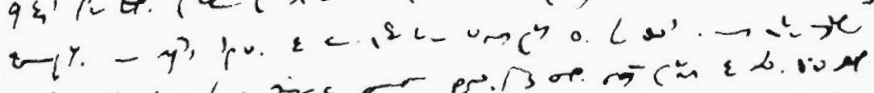

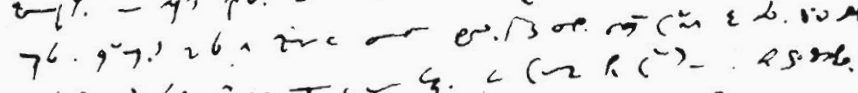

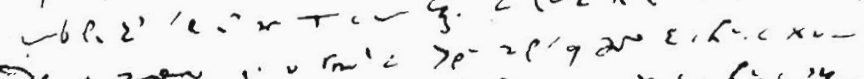

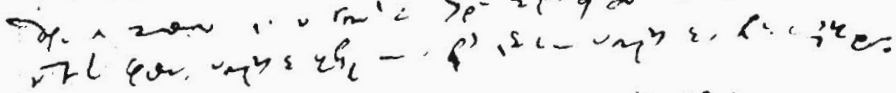

$$
\begin{aligned}
& \text { Graffowe 25\%, foge } \\
& r \operatorname{SL}_{7}
\end{aligned}
$$

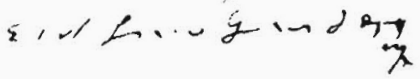

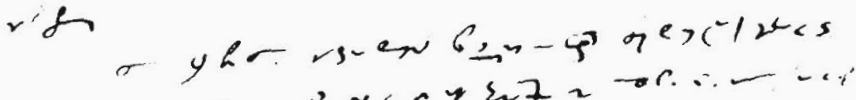

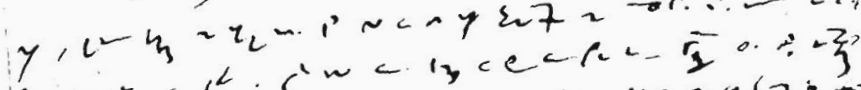

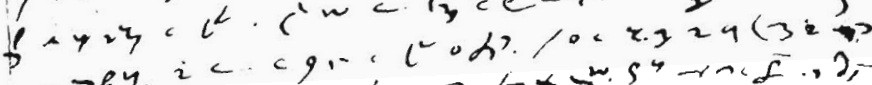

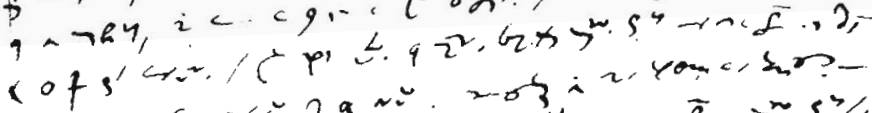

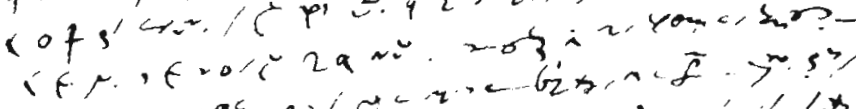

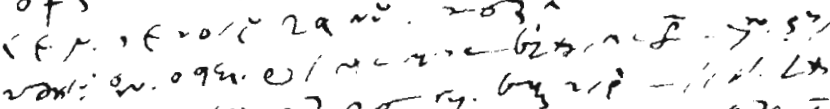

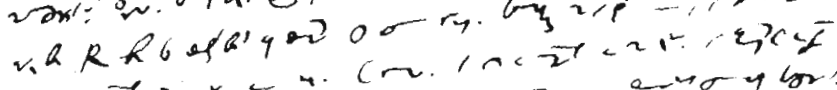

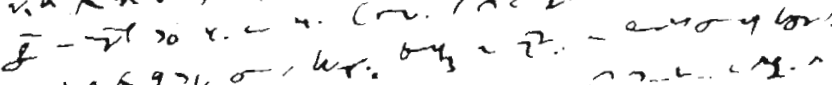

$$
\begin{aligned}
& \text { - }
\end{aligned}
$$

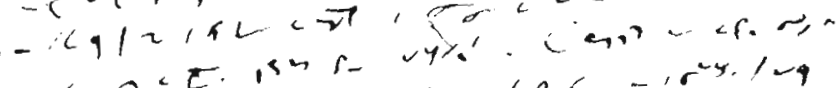

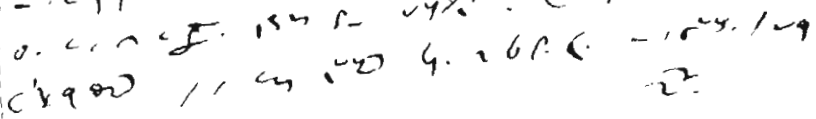

Fig. 7. A shorthand entry by Sir William Clarke, dated Dalkeith, 25 August, 1656. (Courtesy of the Provost and Fellows of Worcester College, Oxford, and Harvester Microforms, see Note 36) 
Wilts. Norwich, 1899, Cmd. 9471.

The Clarke portion of the papers cited above became separated from the main body by Dr. George Clarke's executor, Dr. Shippen, but were subsequently acquired by Worcester College. ${ }^{24}$

\section{Clarke's Shorthand}

In its preface, the booklet accompanying the microform collection states that it contains "a guide to Clarke's 'secret writing' system by the distinguished cryptanalyst, Dr. Eric Sams." 25 Clarke used shorthand for convenience and speed most of the time. The secrecy achieved was usually incidental although shorthand was sometimes employed for this purpose. ${ }^{26}$

Dr. Sams' guide ${ }^{27}$ describes the method he employed to decrypt the shorthand, but does not provide the solution. There are basically two methods of decryptment: counting the frequency of sounds of letters, and discovering the source on which the cipher is based. Sams used the frequency count approach, determining that Clarke used a spelling rather than a sound based shorthand. It is well known, for example, that ' $\mathrm{e}$ ' is the most commonly occurring letter in English, French and German, and, as is wryly noted elsewhere, this is even more true for Olde Englishe. ${ }^{28}$ His analysis of fifteen pages of Clarke's shorthand allowed him to discover some 300 equivalents (i.e. letters, letter combinations, words, etc.), sufficient to identify the source-book. The source-book in turn yielded many more equivalents. Sams concluded that Clarke's shorthand manuscripts can now be deciphered where legible, but that there was no evidence "that any of them had ever been transcribed or read by anyone other that Clarke himself until I did so in 1973." 29

Sams describes the source-book as one of the many editions of Shelton's Tachygraphy published in the 1640s. ${ }^{30}$ His solution to the shorthand was deposited in Worcester College in 1974, although this fact is not mentioned in the guide. ${ }^{31}$ Disappointingly, the solution does not appear to be made available to scholars either through independent publication or as part of the microform set. ${ }^{32}$

\section{Conclusions}

While the microform set includes the large majority of Clarke papers, some are omitted. He kept a diary ${ }^{33}$ while at sea with Monck from April 23 - June 1, 1666, which is in the British Library, along with some other papers. ${ }^{34}$ The collection does, however, include Firth's manuscript notebook (one apparently of several) on the Putney debates.

In summary Clarke's longhand manuscripts have been used extensively by historians for the last century. Some have been published, although experts disagree on how the texts should be interpreted and transcribed. Others have never been used. The shorthand notes seem scarcely to have been examined. 
The papers, therefore, whether previously published or not, remain of great value and potential to historians. ${ }^{35}$ They may even provide answers to the suppositions and enigmas surrounding Clarke's life.

\section{Notes}

1. Peter Redpath (1812-1894) was one of seventeen children of John Redpath, founder of Montreal's first sugar refinery. His wife, Grace, shared his philanthropic enthusiasms until her death in 1907. Together they were among McGill's greatest benefactors, giving amongst other things, a museum, a library, endowments for chairs and book funds, and the historical collection, which included the Tracts. Some of the Tracts are catalogued in S. J. Reid's Catalogue of a Collection of Historical Tracts, 1561-1800 (London, 1901) and machine-readable records for others are being made available through the UTLAS and/or the RLIN databases.

2. John Bramston (1611-1700) of Roxwell, Essex, was a lawyer during the Civil War, in which his family remained neutral. He became an active member of the Cavalier Parliament in 1661, serving on 373 committees. The Tracts formed his personal library. A recent biographical sketch appears in Basil D. Henning's House of Commons, 1660-1690 (London, 1983, vol. 1), while his autobiography was published in the Camden Society Publications, vol. XXXII, 1845.

3. The Tracts were, for example, referred to in Robert B. Downs' Resources of Canadian Academic and Research Libraries (Ottawa, 1967) 232, Lee Ash's Subject Collections, 6th ed. (1985) 1: 813, and Edwin E. Williams' Resources of Canadian University Libraries (Ottawa, 1962) 29.

4. University Microforms International (UMI) plans to complete the collection based on Pollard and Redgrave's Short-title Catalogue, 1475-1640 (STC I) within two years. UMI also published the collection based on Donald Wing's Short.-Title Catalogue, 1641-1700 (STC II), which is currently some two-thirds complete.

5. The Thomason Tracts, an immensely valuable collection of Civil War period tracts housed in the British Library, have been published by UMI. Suzanne Dodson, in her Microform Research Collections: A Guide. 2nd ed. (Westport, 1984) 187, said of this collection:

Those libraries already subscribing to Early English Books: Series II, 1641-1700 would incur total duplication by subscribing to the Thomason Tracts as well.

This assessment appears to be erroneous. Although Unit I of Thomason and Unit VII of Early English Books, Series II, are identical, this represents a duplication of only $20 \%$ of Thomason. UMI will not include any further Thomason titles in STC II until the ultimate units of the project. These final units will also be duplicates, although libraries with Thomason need not purchase them. What Dodson overlooks is the titles in Thomason which are out of the scope of STC II and will not be duplicated at all. 
These would include over 7000 periodical issues, foreign language materials and manuscripts, totalling some $30 \%$ of the items in the collection (Catalogue of the Thomason Tracts, I: xxi).

6. Research Publications published the Goldsmith-Kress Library of Economic Literature. This set is based on the holdings of two outstanding collections of early publications on the topic: the Goldsmith's Library in London and the Kress Library at Harvard.

7. To date three grants have been received totalling almost $\$ 100,000$.

8. Harvester's titles for these collections have been used here. A full description of each one can be found in the Harvester Catalogue.

9. Although the Lansdowne Collection is of greater importance than some of the others, the microforms are held elsewhere in Canada. For this reason it holds a lower acquisitions priority at McGill Universtiy. [Editor's note: since this article was accepted, the Harleian, Tanner and Balland Collections have been acquired.]

10. Historical Manuscripts Commission Report on the Manuscripts of F.W. Leyborne-Popham (Norwich, 1899) contains several items which shed some light on Clarke's family. A letter (106) is signed by "thy humble servant and mother, Elizabeth Mosse." This lady, who lived with Clarke's wife and was familiar with his family, is almost certainly a foster mother. Clarke himself referred to her as "Mother Mosse." Clarke also had a younger brother, Jacob, still at school in 1652 (102-103), and a sister, Betty, who married the same year. His remaining relatives mentioned in the papers, with the possible exception of John Collins, a Chief Butler and Steward of the Inner Temple, seemed to be through his marriage to Dorothy Hilliard (Hyliard) in 1648.

11. In a booklet accompanying the microform set entitled Sir William Clarke Manuscripts 1640-1664, there is an "Introduction" by G. E. Aylmer, Master of St. Peter's College and general editor of the publication, in which this educational background is given. The evidence for this seems to be nothing more than the coincidence of a rather common name. In fact Clarke's career is wholly inconsistent with entering the Inner Temple and being called to the bar at the dates listed. The $D N B$ (1887) also listed the same educational background (as did C. H. Firth, the first scholar to use Clarke's papers) but in the Corrections and Additions to the DNB (1966) it is acknowledged there is no satisfactory ground for the identification. Other historians have confused the various William Clarkes of the period. For example, on August 4th, 1654, Oliver Cromwell signed a warrant for payment to William Clarke, Doctor of Laws, of $£ 66$ 13s. 4d. salary for four months as Advocate of the Commonwealth (Rawlinson Manuscripts, A: 328, 108-9). W. C. Abbott, who cited this manuscript in his Writing and Speeches of Oliver Cromwell (Cambridge, Mass., 1945) III: 390-1, wrongly describes this Clarke as "...for many years Monck's Secretary, now Doctor of Law..." Sir William Clarke's long service with Monck only began with the General's return to Scotland in January, 1654. Dr. William Clarke (Clerk in the DNB) was an Admiralty Judge, who in 1653-54 took on the extra responsibility of Judge 
Advocate to the Admiralty for $£ 200$ per year (Calendar of State Papers Domestic, 1652-53 xxxiv: 245).

Another instance occurs in Maurice Ashley's General Monck (London, 1977), in which he cited a letter, dated 1646, to Monck from his sister mentioning she received documents brought by 'Captain Clearke' (p.268). Ashley contends the date is wrong because the "Captain Clearke referred to in the letter did not become Monck's secretary until 1654." While Ashley is almost certainly correct about the misdating, it is equally sure that William Clarke was not a Captain and his secretarial duties did not include carrying the General's mail from Scotland to Devon.

12. Other assistants at this time were Richard Hatter, Thomas Wragg, Thomas Margetts, Robert Spavin (Cromwell's Secretary) and Gilbert Mabbott (who later married Clarke's wife's sister and became editor of The Moderate). It is clear that some, probably all, of these secretaries learned the same shorthand, for Rushworth wrote to Clarke "send of ten but write very cautiously unless you write in shorthand..." (HMC Leyborne-Popham 79)

13. C. H. Firth's The Clarke Papers (London, 1891), I: ix. (Camden Society. Publications. New Series 49)

14. Ibid. Ixxvi.

15. Ibid, vii-viii.

16. Aylmer, in the "Introduction" noted in footnote 11 , finds evidence for this in a tract on the King's speech from the scaffold published in 1649 and once owned by Clarke. In this there is a handwritten asterisk next to an unidentified "Gentleman" on the scaffold. Against a corresponding asterisk in the margin there are the initials W. C. This Aylmer regards as "morally, although doubtless not legally, certain proof" of Clarke's presence there (23).

17. Fairfax disapproved of the regicide and refused the republican loyalty oath (Aylmer, "Introduction," (noted in footnote 11) 10). He was not present on the scaffold and it has been suggested that he was kept unaware of the time of the execution. It therefore seems unlikely his secretary, Clarke, would have been there. If Aylmer is partially correct and that there was an individual with the initials W. C. on the scaffold, there are other likely candidates. Sir William Constable and William Cawley were both MP's, commissioned to sit in judgement on the King and were both committed regicides who signed the death sentence. Constable may be a favourite in that he was also charged with guarding the King in his captivity in the Isle of Wight from January 4th, 1648, under Colonel Robert Hammond (John Rushworth, Historical Collections, 2nd ed., London, 1721, VII 955).

18. The fullest account of the King's trial was published by Gilbert Mabbott, then Censor and Licensor of the press, under the title A Perfect Narrative of the Proceedings of the High Court of Justice in the Tryall of the King. C. V. Wedgwood in her book The Trial of Charles I. (London, 1964) mentions the Perfect Narrative is based on a shorthand account by ' $\mathrm{C}$. W.' She states in the 'Bibliographical Note' (p.227) "this shadowy figure does not seem to be otherwise identifiable." Clarke was not only present at the 
trial but also, on his own evidence in the 1660 trial of Thomas Harrison, "took notice of it in a book" (Cobbett's complete State Trials, V 1018). Since he was Mabbott's friend and brother-in-law, it seems highly likely that he was the shadowy and unidentified ' $C$. W.', utilizing the transparent device of initial transposition. Oddly, the U. S. edition of Wedgwood's work, reset and published under the title $A$ Coffin for King Charles, has an abbreviated 'Bibliographical Note' in which mention of ' $\mathrm{C}$. W'. is omitted.

19. Noted in Firth, The Clarke Papers, II, ix. This purchase involved Clarke in a legal dispute with his uncle, John Collins, mentioned in note 10. In 1674, Collins wrote Mysteria Revelata in which he claimed to have been introduced to Monck by Clarke and that it was he who persuaded Monck to support the restoration of the monarchy. Little credence can be given to this latter claim, penned af ter both Clarke and Monck were dead.

20. Monck's assessment is found in his dispatch from aboard the "Royal Charles" at the Nore on June 28th, 1666, to Charles II (Calendar of State Papers Domestic 1665-66, CLX 471).

21. Part or all of this land was the St. John's Wood purchase in 1651 granted or regranted after the Restoration.

22. Cobbett's Complete State Trials. V, 1018 - 1074.

23. It is interesting to note that in other trials of regicides where testimony was required as to whether an individual was on the scaffold, Clarke was not called although he was in court - a further indication that he may not have been present at the execution.

24. HMC. Leyborne-Popham x-xi.

25. Sir William Clarke Manuscripts 29-32.

26. See note 12 for evidence of this.

27. Sir William Clarke Manuscripts "preface" 7.

28. E. Sams and J. Moore 'Cryptanalysis and Historical Research' Times Literary Supplement March 4th, 1977: 253.

29. Sir William Clarke Manuscripts, 29. It is clear, however, from note 12, that some of Clarke's contemporaries could read his shorthand. C. $\mathrm{H}$. Firth also indicated that he knew the substance of some shorthand entries (Ibid 37).

30. Thomas Shelton, 1601?-1650, produced many editions of his shorthand texts. Between 1626 and 1649, when Shelton radically altered his system, there were at least fifteen editions. Two of those, A Tutor to Tachygraphy, or Short-writing (1642) and Tachygraphy (1647) were reprinted in 1970 by the Augustan Reprint Society. Samuel Pepys used Shelton's system for almost all his diary. Interestingly, Pepys knew Clarke fairly well and refers to him several times in the diary. On March 28th, 1666, he described Clarke as "mighty" and a "brisk blade." The entry for July 12, 1666, conveys Sir 
William Coventry's opinion that Clarke was one of the "sorry instruments" by which Monck did great things.

31. TLS. loc. cit.

32. A puzzled enquiry to Harvester Microform did not shed light on this curious omission. Publication would normally be standard policy for Harvester, who did ascertain that the solution is in the Worcester College Library with no restriction as to copying. Its exclusion from the microform set remains something of a mystery.

33. British Museum. Additional Manuscript 14286.

34. Aylmer "Introduction" (noted in footnote 11) 26, note 23 provides a good listing of Clarke materials which are not part of the microform set.

35. The microfilming is of generally excellent quality, with high contrast between text and background. Historians should have no difficulty with legibility. Deciphering the shorthand entries will, however, prove a laborious task until a measure of expertise in Shelton's system and Clarke's idiosyncrasies has been gained.

36. Figures 6 and 7 were taken from a photocopy of the microfilm of the Clarke Papers, volume XXVIII. They are reproduced here with the kind permission of the Provost and Fellows of Worcester College, Oxford, and Harvester Microforms. 